\title{
Protein denaturation in frozen stored hake (Merluccius merluccius L.) muscle: The role of formaldehyde
}

Carmen G. Sotelo, Santiago P. Aubourg, Ricardo I. Perez-Martin \& Jose Manuel Gallardo

Instituto de Investigaciones Marinas CSIC, Eduardo Cabello 6, 36208-Vigo, Spain

Protein solubility of whole and minced muscle of hake (Merluccius merluccius L.) was evaluated at different temperatures of storage: $-5^{\circ},-12^{\circ}$ and $-20^{\circ} \mathrm{C}$. Proteins soluble in $1 \% \mathrm{NaCl}$ did not show any change at any of the temperatures of storage, while the $5 \%$ $\mathrm{NaCl}$-soluble proteins decreased significantly when whole hake was stored at $-5^{\circ}$ and $12^{\circ} \mathrm{C}(\mathrm{p}<0.01)$. A correlation was found between the decrease of solubility and the production of formaldehyde at $-5^{\circ}$ and $-12^{\circ} \mathrm{C}$ ( $\mathrm{p}<0.001$ and $\mathrm{p}<0.01$, respectively). Bound formaldehyde (formaldehyde not extractable) increased with storage time at $-5^{\circ}$ $(\mathrm{p}<0-001)$.

The addition of formaldehyde to the minced muscle brought about a decrease in both the $1 \%$ and the $5 \% \mathrm{NaCl}$-soluble proteins. The decrease was dependent upon the temperature, the amount of formaldehyde added and the time of storage. The role of formaldehyde in the denaturation of sarcoplasmic proteins was confirmed by measuring trimethylamino oxide demethylase activity during the experiment.

\section{INTRODUCTION}

Frozen storage offers a means of preserving fish; however, during frozen storage, quality is lost due to a deterioration of texture, flavour and colour, especially after long periods of storage, when poor freezing practices are employed or when the initial fish quality is low. The main problem is the change of texture which reduces consumer acceptability (Sikorski et al., 1976; Shenouda, 1980). Texture changes are the result of denaturation of muscle proteins, particularly those in the myofibrillar fraction (Haard, 1992). For these reasons, different methods of measuring protein denaturation have been used to follow textural deterioration. Among them, protein solubility is one of the most often chosen, because of its simplicity and relatively good correlations with textural characteristics (Shenouda, 1980; De Koning \& Mol, 1991). Solubility of muscle 
proteins, in particular buffers, reflects changes in their unique chemical and threedimensional structure, changes that are usually referred to as denaturation (Nakai et al., 1991).

Denaturation of muscle proteins has been attributed to different factors, fish species being one of them. Basically, fish species can be divided into two groups based on the possession or not of trimethylamine oxide demethylase (TMAOase), which degrades trimethylamine oxide (TMAO) to dimethylamine (DMA) and formaldehyde (FA) during iced and/or frozen storage. The enzyme is mostly found in the viscera and red muscle of fishes belonging to gadoid species (Mackie \& Thomson, 1974; Hebard et al., 1982; Haard, 1992). During frozen storage, a strong relationship between the production and accumulation of FA and the deterioration of texture in muscle of this group of fish has been found (Dingle et al., 1977; Gill et al., 1979; Matthews et al., 1980; Parkin and Hultin, 1982a; Kelleher et al., 1981; Jahncke et al., 1992). Although FA might react with proteins during frozen storage, it is still not clear how FA accelerates protein denaturation (Ang \& Hultin, 1989).

Hake, fish belonging to the Order Gadiformes, are gaining importance as fisheries, as cod are increasingly being depleted (Morrow, 1992). These species represent the main high-quality white-fleshed fish in some European countries, such as Spain (Whitaker, 1980), where they are very often sold in the frozen state. It is also an important source of derived frozen products. There are some data on storage properties of frozen South Atlantic hake, Merluccius hubbsi and M. gayi (Almandos et al., 1984; Ciarlo et al., 1985) M. bilinearis (Hiltz et aL, 1976; Licciardello et al., 1980), M. productus (Crawford et al., 1979) and M. capensis (De Koning \& Mol, 1991). Also, it has been reported that there are changes in some sensory and chemical parameters in European hake (Merluccius merluccius) during ice and frozen storage (Pérez-Villarreal \& Howgate, 1987, 1991). However, there are no data on changes in muscle protein solubility of frozen stored European hake.

Temperatures such as $-18^{\circ} \mathrm{C}$ and $-20^{\circ} \mathrm{C}$ are recommended for storage of frozen fish in retail cabinets, but these temperatures may rise to $-12^{\circ} \mathrm{C}$ or even higher. This might adversely affect the quality, depending upon the period that fish are maintained under those conditions (Singh \& Wang, 1977). The objective of this study was to follow 
changes in protein solubility and FA production of hake (Merluccius merluccius L.) muscle when the whole fish was stored at temperatures that might be attainable in retail outlets or home freezers, $-5^{\circ} \mathrm{C},-12^{\circ} \mathrm{C}$ and $-20^{\circ} \mathrm{C}$. Also, minced muscle was used as a model system for adding different amounts of FA and for evaluating the role of excess of FA on protein solubility during storage at the above temperatures.

\section{MATERIALS AND METHODS}

Storage of whole hake

Hake (Merluccius merluccius L.), varying in weight from 0.5 to $0-8 \mathrm{~kg}$, were obtained from the local fish market $24 \mathrm{~h}$ after catching. The fish had been eviscerated when landed and each individual was measured and weighed. Each fish was immediately blast-frozen until it reached a temperature of $-40^{\circ} \mathrm{C}(2 \mathrm{~h})$. Each frozen fish was packed in a polyethylene bag and randomly divided into three batches, which were stored at $5^{\circ},-12^{\circ}$ and $-20^{\circ} \mathrm{C}$ respectively. At definite intervals, $1-3$ individuals were removed from frozen storage, thawed $\left(4^{\circ} \mathrm{C}\right.$, overnight $)$ and prepared for analysis by deboning and mincing the flesh.

Storage of minced muscle after FA addition

Another batch of eviscerated hake was purchased at the local fish market. The fish were skinned, deboned and minced, then flesh of different individuals was pooled into one batch. The homogenised flesh was distributed in plastic containers and FA (diluted with distilled water from a $37 \%$ solution, Baker) was added and evenly distributed by using an Ultra-Turrax tissue macerator (9500 rpm for $1 \mathrm{~min}$ ). FA concentrations attained in the samples were $80,160,320$ and 640 ppm.

The FA concentration of the stock solution was measured by iodine titration (Treadwell, 1921).

All samples were frozen at $-30^{\circ} \mathrm{C}(24$ hours) and after this period they were split into three batches, each of them maintained at the following temperatures: $-5^{\circ},-12^{\circ}$ and $20^{\circ} \mathrm{C}$ up to a maximum period of six months. 
Protein solubility determination

In the case of frozen storage of whole hake, the method employed was similar to that described by Laird et al. (1980). One gram of minced muscle was homogenised with cold 1\% NaC1, $20 \mathrm{mM} \mathrm{NaHCO}_{3} \mathrm{pH}$ 7.0, by using an Ultra-Turrax (1 min at $9500 \mathrm{rpm}$ ). The homogenate was then centrifuged at $13000 \mathrm{x}$ g for $20 \mathrm{~min}$; the supernatant was made up to $100 \mathrm{ml}$. This fraction was considered as the $1 \% \mathrm{NaCl}$-soluble protein. The pellet was resuspended in cold 5\% $\mathrm{NaC} 1,20 \mathrm{mM} \mathrm{NaHCO}_{3} \mathrm{pH} 7.0$ and then centrifuged at $13000 \mathrm{x}$ g for $20 \mathrm{~min}$. The supernatant was made up to $100 \mathrm{ml}$ and considered as the $5 \% \mathrm{NaCl}$-soluble protein.

The 1\% NaC1- and 5\% NaCl-soluble proteins of FA-added minced muscle were extracted as shown in The protein in all fractions was determined by the method of Lowry et al. (1951).

FA and DMA determination

FA was determined by the spectrophotometric method of Nash (1953) in an aqueous extract of the muscle. This extract was obtained by steam distillation of the muscle in the presence of 85\% phosphoric acid (Rehbein, 1987).

DMA was determined by the spectrophotometric method described by Mackie \& Thomson (1974).

Statistical analysis

Linear regression analysis of changes of soluble protein, free and bound FA and DMA versus time of storage were made with the data obtained from 1-3 individuals per period and temperature in the case of whole hake storage. Correlation analysis were carried out when comparing two measured variables.

\section{RESULTS}


Frozen storage of whole hake

The $1 \% \mathrm{NaCl}$-soluble proteins of whole hake stored at $-5^{\circ},-12^{\circ}$ and $-20^{\circ} \mathrm{C}$ did not show any significant change (data not shown). Regression analysis of 5\% NaCl-soluble protein values belonging to different individuals showed that the solubility of the hakes stored at $-5^{\circ}$ and $-12^{\circ} \mathrm{C}$ decreased significantly $(\mathrm{p}<0.01)$, as can be seen in Fig. 2 . It also can be observed that solubility is lesser with higher temperature of storage.

FA was produced during the frozen storage of whole hake muscle. The increase in FA was very dependent upon the temperature of storage, being greatest at $-5^{\circ} \mathrm{C}(\mathrm{p}<0.01)$ and less at $-12^{\circ} \mathrm{C}(\mathrm{p}<0.01)$, while at $-20^{\circ} \mathrm{C}$ no significant changes were observed (Fig. 3).

A correlation test was carried out between FA produced by the muscle and the $5 \%$ $\mathrm{NaCl}$-soluble proteins. Correlation coefficients show that there are significant correlations between the decrease in $5 \% \mathrm{NaCl}$-soluble protein at $-5^{\circ} \mathrm{C}$ and $-12^{\circ} \mathrm{C}$ and the increase in FA at those temperatures $\left(-5^{\circ} \mathrm{C}: \mathrm{r}^{2}=-0.767, \mathrm{p}<0.001 ;-12^{\circ} \mathrm{C}: \mathrm{r}^{2}=-0.703, \mathrm{p}\right.$ $<0.01 ;-20^{\circ} \mathrm{C}: \mathrm{r}^{2}--0-347, \mathrm{p}>0.05$, n.s.).

DMA was also determined. As expected, the data were consistent with FA changes, since they are both products of TMAOase (Parkin \& Hultin, 1982b) (Fig. 4).

It has been shown that DMA and FA values may differ. Although both compounds, DMA and FA, are produced equimolecularly, the recovery of all FA produced might be reduced because of the high reactivity of FA with different compounds (free amino acids, nucleotides and proteins). In Fig. 5, FA has been subtracted, calculated from measured DMA values, and FA determined by distillation. This FA has been called bound FA. It can be observed that bound FA increases with storage time at $-5^{\circ} \mathrm{C}(\mathrm{p}<$ 0.001 ) but does not change with storage time at $-12^{\circ} \mathrm{C}$ and $-20^{\circ} \mathrm{C}$.

Frozen storage of minced muscle and FA addition 
The highest level of FA found in the experiment of the whole hake was $134 \mathrm{ppm}$. The chosen values of added FA are those expected of gadoid fish (80 and 160 ppm) or sometimes in excess values (320 and 640 ppm) (Castell et al., 1973).

Adding FA to minced hake muscle and frozen-stored resulted in a rubbery texture depending upon the amount of FA added and the temperature of frozen storage. Both $1 \%$ and $5 \% \mathrm{NaCl}$-soluble proteins caused changes related to the amount of FA added and the temperature of storage (Figs 6 and 7). However, the loss of solubility was more marked in the case of $5 \% \mathrm{NaCl}$-soluble proteins, as was expected. When no FA was added to the muscle, $1 \% \mathrm{NaCl}$-soluble proteins did not cause any change at any temperature studied. When FA is added, a decrease in $1 \% \mathrm{NaCl}$-soluble proteins was noticed with time of storage at $-12^{\circ} \mathrm{C}$ and $-20^{\circ} \mathrm{C}$. Surprisingly, at $-5^{\circ} \mathrm{C}$ no changes could be detected with storage time, but differences were observed between each of the different levels of added FA. The same could be observed in 5\% $\mathrm{NaCl}$-soluble proteins.

The role of FA in denaturation of sarcoplasmic proteins as confirmed by measuring DMA produced in he minced muscle after adding FA. Figure 8 shows MA produced at different temperatures of storage with different amounts of FA added. FA promoted the inhibition of the TMAOase (DMA and FA producing enzyme). The inhibition was greater at $-5^{\circ} \mathrm{C}$ and dependent upon the amount of FA added: the higher the amount of added FA the less DMA was produced. The same occurred at $-12^{\circ} \mathrm{C}$ although the production was less than at $-5^{\circ} \mathrm{C}$, and at $-20^{\circ} \mathrm{C}$ it was even less than at $-12^{\circ}$ and $-5^{\circ} \mathrm{C}$. Although it can be said that FA inhibited the enzyme because it is a product of the catalysis of TMAOase, the solubility data might suggest a mechanism of denaturation of the enzyme. Again, it can be observed that low temperature of storage inhibits both the production of FA and denaturation of the enzyme.

\section{DISCUSSION}

Frozen storage of whole hake

The $5 \% \mathrm{NaCl}$-soluble proteins were affected while the $1 \% \mathrm{NaCl}$-soluble proteins did not show any changes in solubility with storage time at $-5^{\circ},-12^{\circ}$ and $-20^{\circ} \mathrm{C}$. This might reflect a higher sensitivity of the $5 \% \mathrm{NaCl}$-soluble proteins to denaturation on freezing 
and frozen storage at different temperatures compared to the $1 \% \mathrm{NaCl}$-soluble protein. This is understandable as $1 \% \mathrm{NaCl}$-soluble proteins are mainly globular sarcoplasmic proteins, whereas $5 \% \mathrm{NaCl}$-soluble proteins are mainly the myofibrillar fraction of the muscle proteins (Shenouda, 1980). The same results have been found by other authors Tor different species of gadoids (Tejada et al., 1984). However, other techniques, such as electrophoresis or liquid chromatography, have shown that the sarcoplasmic fraction might also be affected, although to a lesser extent than the myofibrillar fraction (Rehbein, 1985; Onishi \& Rodger, 1980; LeBlanc \& LeBlanc, 1992; Owusu-Ansah \& Hultin, 1992).

It has been suggested that FA is the main causative factor of denaturation of muscle proteins in frozen stored gadoid fish (Matthews et al., 1980; Parkin \& Hultin, 1982b). As would be expected, a correlation was found between FA production and decrease in protein solubility. In high FA-producing fish, such as red hake (Urophycis chuss), lowionic-strength soluble proteins were denatured (LeBlanc \& LeBlanc, 1992; OwusuAnsah \& Hultin, 1992). In our study, a decrease in the $1 \% \mathrm{NaCl}$-soluble proteins was found when FA was added to minced muscle, indicating that the amount of FA is possibly of some importance in denaturing sarcoplasmic proteins and also in the state of tissue disruption (Parkin \& Hultin, 1982a).

It also was found that bound FA was dependent upon the temperature and time of storage, in agree ment with the findings of Owusu-Ansah and Hultin (1986) for red hake at $-7^{\circ} \mathrm{C}$. The high reactivity of FA with amino acids, nucleotides and proteins (Poulter \& Lawrie, 1979) might explain the existence of bound FA, and also the differences in the sensitivity of the FA and DMA tests (Kelleher et al., 1981).

If FA reacts with proteins, the highest differences between the DMA and FA concentrations would be found at the early stages of storage when the amount of FA is low and all protein target sites are, in theory, free. On the other hand, we found that bound FA increased with storage time. This suggests that changes are necessary in the target sites for the reaction to take place, or the way in which FA is produced would determine its reactivity and the time needed for the reaction to take place. 
When FA was added to the minced muscle it led to a decrease in solubility that was very dependent upon the FA concentration, but was not so dependent upon the time of storage at $-5^{\circ} \mathrm{C}$. This means that $\mathrm{FA}$ reacts very quickly with proteins and nonprotein nitrogen (measured as a decrease in solubility in this study). Bearing in mind that mincing (tissue disruption) destroys the natural structures and compartments that normally exist in the tissue, it is possible that reaction limitation could in fact be a matter of availability of reactants (FA, protein targets). Is FA available to its targets, in our ease proteins, during frozen storage? TMAOase has been found to be an enzymic complex, a constituent of lysosomal membranes (Gill \& Paulson, 1982; Parkin \& Hultin, 1986; Joly et al., 1992). Recently, it has been shown that storage of cod muscle at $-12^{\circ} \mathrm{C}$ revealed extensive condensation of sarcoplasmic reticulum membrane (Ablett \& Gould, 1992). Changes in the integrity of membranes as storage progresses might also reflect different stages in the release of FA and DMA, if both compounds were produced inside subcellullar organules (e.g. lysosomes). Raising the temperature of storage even for short periods of time, regardless of subsequent reduction of temperature, promotes diffusion and redistribution of reactants and metabolites, facilitating the occurrence of deteriorative reactions (LeBlanc \& LeBlanc, 1988). This could explain the fact that insolubility increases gradually during frozen storage and bound FA also increases gradually. Also, it is known that FA reacts more easily with already-denatured proteins (Ang \& Hultin, 1989; Sotelo \& Mackie, 1993). So, as frozen storage progresses, the proteins become more susceptible to reaction with FA, according to the hypothesis of Ang and Hultin (1989) in which the role of FA is suggested to be that of an accelerator of protein denaturation.

\section{ACKNOWLEDGEMENT}

The authors wish to thank CICYT for the financial support of the project 608/516 ALI 88-0145-CO2-02.

\section{REFERENCES}

Ablett, R. F. \& Gould, S. P. (1992). Subcellular membrane integrity of Atlantic cod (Gadus morhua) myotomal tissue: Effects of frozen storage. J. Food Sci., 57, 796-9. 
Almandos, M. E., Giannini, D. H., Ciarlo, A. S. \& Boeri, R. L. (1984). Relationship between the increase of total volatile bases and dimethylamine in frozen Patagonian hake (Merluccius hubbsi). Lebensm.- Wiss u.- Technol., 17, 111-3.

Ang, J. F. \& Hultin, H. O. (1989). Denaturation of cod myosin during freezing after modification with formaldehyde. J. Food Sci., 54, 814-18.

Castell, C. H., Smith, B. \& Dyer, W. J. (1973). Effects of formaldehyde on salt extractable proteins of gadoid muscle. J. Fish. Res. Board. Can., 30, 1205-13.

Ciarlo, A. S., Boeri, R. L. \& Giannini D. H. (1985). Storage life of frozen blocks of Patagonian hake (Merluccius hubbsi) filleted and minced. J. Food Sci., 50, 723-6.

Crawford, D. L., Law, D. K., Babbitt, J. K. \& McGill, L. A. (1979). Comparative stability and desirability of frozen Pacific hake fillet and minced flesh blocks. J. Food Sci., 44, 363-7.

De Koning. A. J. \& Mol, T. H. (1991). Quantitative quality test for frozen fish: Soluble protein and free fatty acid content as quality criteria for hake (Merluccius capensis) stored at $-18^{\circ} \mathrm{C}$. J. Sci. Food Agric., 54, 440-58.

Dingle, J. R., Keith, R. A. \& Lall, B. (1977). Protein instability in frozen storage induced in minced muscle of flatfishes by mixture of muscle red hake. Can. Inst. Food Sci. Technol. J., 10, 143-6.

Gill, T. A. \& Paulson, A. T. (1982). Localization, characterization and partial purification of TMAOase. Comp. Biochem. Physiol., 71B, 49-56.

Gill, T. A., Keith, R. A. \& Smith-Lall, B. (1979). Textural deterioration of red hake and haddock muscle in frozen storage as related to chemical parameters and changes in myofibrillar proteins. J. Food Sci., 44, 661-7.

Haard, N. F. (1992). Biochemical reactions in fish muscle during frozen storage. In Seafood Science and Technology. ed. E. G. Bligh. Fishing News Books, Oxford, UK, pp. 176-209.

Hebard, C. H., Flick, G. J. \& Martin, R. E. (1982). Occurrence and significance of TMAO and its derivatives in fish and shellfish. In Chemistry and Biochemistry of Marine Food Products, ed. R. E. Martin, G. J. Flick \& D. R. Waard. AVI Publishing Co., Westport, Connecticut, pp. 149-304.

Hiltz, D. F., Lall, B. S., Lemon, D. W. \& Dyer, W. J. (1976). Deteriorative changes during frozen storage in fillets and minced flesh of silver hake (Merluccius bilinearis) processed from round fish held in ice and refrigerated sea water. J. Fish. Res. Bd. Can., 33, 2560-7. 
Jahncke, M., Baker, R. C. \& Regenstein, J. M. (1992). Frozen storage of unwashed cod (Gadus morhua) frame mince with and without kidney tissue. J. Food Sci., 57, 57580.

Joly, A., Cottin, P., Han-Ching, L. \& Ducastaing, A. (1992). Trimethylamine N-oxide demethylase (TMAO-ase) of saithe (Pollachius virens) kidney: A study of some physicochemical and enzymic properties. J. Sci. Food Agric., 59, 261-7.

Kelleher, S. D., Buck, E. M., Hultin, H. O., Parkin, K. L., Licciardello, J. J. \& Damon, R. A. (1981). Chemical and physical changes in red hake blocks during frozen storage. J. Food Sci., 47, 65-70.

Laird, W. M., Mackie, I. M. \& Hattula, T. (1980). Studies of the changes in the proteins of cod-frame minces during frozen storage at $-15^{\circ} \mathrm{C}$. In Advances in Fish Science and Technology, ed. J. J. Connell. Fishing News (Books) Ltd, Farnham, Surrey, UK, pp. 428-34.

LeBlanc, E. L. \& LeBlanc, R. J. (1988). Effect of frozen storage temperature on free and bound formaldehyde content of cod (Gadus morhua) fillets. J. Food Proc. Preserv., 12, 95-113.

LeBianc, E. L. \& LeBlanc, R. J. (1992). Determination of hydrophobicity and reactive groups in proteins of cod (Gadus morhua) muscle during frozen storage. Food Chem., 43, 3-11.

Licciardello, J. J., Ravesi, E. M. \& Allsup, M. G. (1980). Frozen storage characteristics of whiting blocks. Marine Fisheries Rev., 42, 55-60.

Lowry, O. H., Rosebrough, N. J., Farr, A. L. \& Randall, R. J. (1951). Protein measurement with the Folin phenol reagent. J. Biol. Chem., 193, 265-75.

Mackie, I. M. \& Thomson, B. W. (1974). Decomposition of trimethylamine oxide during iced and frozen storage of whole and comminuted tissue of fish. Proc. IVth Int. Congr. Food Sci. \& Technol., I, 243-50.

Matthews, A. D., Park, G. R. \& Anderson, E. M. (1980). Evidence for the formation of covalent cross-linked myosin in frozen-stored cod minces. In Advances in Fish Science and Technology, ed. J. J. Connell. Fishing News (Books) Ltd. Farnham, Surrey, UK, pp. 438-44.

Morrow, J. B. (1992). A changing industry: From internal evolution to external responsiveness. In Seafood Science and Technology, ed. E. G. Bligh. Fishing News Books, London, UK, pp. 1-11. 
Nakai, S., Li-Chan, E., Hirotsuka, M., Vazquez, M. C. \& Arteaga, G. (1991).

Quantitation of hydrophobicity for elucidating the structure-activity relationships of food proteins. In Interactions of Food Proteins, ed. N. Parris \& R. Barford. ACS Symposium Series 454, American Chemical Society, Washington DC, pp. 42-58.

Nash, T. (1953). The colorimetric estimation of formaldehyde by means of the Hantzsch reaction. Biochem. J., 55, 416-21.

Onishi. M. \& Rodger, G. W. (1980). Effect of formaldehyde addition at different ionic strengths on the salt soluble proteins of fish muscle. In Advances in Fish Science and Technology, ed. J. J. Conneil. Fishing News (Books) Ltd, Farnham, Surrey, UK, pp 459-67.

Owusu-Ansah, Y. J. \& Hultin, H. O. (1986). Chemical and physical changes in red hake fillets during frozen storage. J. Food Sci., 51, 1402-6.

Owusu-Ansah, Y. J. \& Hultin, H. O. (1992). Differential insolubilization of red hake muscle proteins during frozen storage. J. Food Sci., 57, 265-6.

Parkin. K. L. \& Hultin, H. O. (1982a). Some factors influencing the production of dimethylamine and formaldehyde in minced and intact red hake muscle. J. Food Process. Preserv., 6, 73-97.

Parkin, K. L. \& Hultin, H. O. (1982b). Fish muscle microsomes catalyze the conversion of trimethylamine oxide to dimethylamine and formaldehyde. FEBS Lett., 139, 614.

Parkin, K. L. \& Huitin, H. O. (1986). Characterization of trimethylamine-N-oxide (TMAO) demethylase activity from fish muscle microsomes. J. Biochem., 100, 7786.

Pérez-Villarreal, B. \& Howgate, P. (1987). Spoilage of European hake (Merluccius merluccius) in ice. J. Sci. Food Agric., 41, 335-50.

Pérez-Villarreal, B. \& Howgate, P. (1991). Deterioration of European hake (Merluccius merluccius) during frozen storage. J. Sci. Food Agric., 55, 455-69.

Poulter, R. G. \& Lawrie, R. A. (1979). Studies on fish muscle protein: Nutritional consequences of adding low concentration of formaldehyde and/or linoleic acid to cod muscle. Lebensm. Wiss. Technol., 12, 47-51.

Rehbein, H. (1985). Does formaldehyde form cross-links between myofibrillar proteins during frozen storage of fish muscle? Refrig. Sci. Technol., 4, 93-99.

Rehbein, H. (1987). Determination of the content in fishery products. Z. Lebensm. Unters. Forsch., 185, 292-8. 
Rehbein, H. \& Karl, H. (1985). Solubilization of fish muscle proteins with buffers containing sodium dodecyl sulphate. Z. Lebensm. Unters Forsch., 180, 373-8.

Shenouda, S. Y. K. (1980). Theories of protein denaturation during frozen storage of fish flesh. Adv. Food Res., 26, 275-311.

Sikorski, Z., Olley, J. \& Kostuch, S. (1976). Protein changes in frozen fish. Crit. Rev. Food Sci. Technol., 8, 97-129.

Singh, R. P. \& Wang, C. Y. (1977). Quality of frozen foods-A review. J. Food Proc. Eng., 1, 97-127.

Sotelo, C. G. \& Mackie, I. M. (1993). The effect of formaldehyde on the aggregation of BSA during frozen storage of model systems in the presence of amino acids, carboxylic acids and sorbitol. Food Chem., 47, 263-70.

Tejada, M., Borderias, A. J. \& Jimenez-Colmenero, F. (1987). Myofibrillar and sareoplasmic proteins: Their role in alterations in certain functional properties of muscle during frozen storage. Proc. IUFoST Int. Symp. Chem. Changes Food Proc. Instituto de Agroquimica y Tecnologia Alimentos (CSIC) Valencia, Spain, pp. 10314.

Treadwell, F. P. (1921). Tratado de Quimica Analitica. II. Analisis Cuantitativo, ed. M. Matin, Barcelona. Whitaker, D. R. (1980). World utilization of hake. Mar. Fish Rev., 42, 4-7. 
Fig. 1. Protocol for the extraction of $1 \%$ and $5 \% \mathrm{NaCl}$-soluble proteins in minced muscle with FA added.

Fig. 2. Decrease in 5\% NaCl-soluble protein of whole hake muscle during frozen storage. Regression lines were plotted in each case; coefficients $\left(r^{2}\right)$, significance and number of individuals analysed (n) were as follows: $-5^{\circ} \mathrm{C}: \mathrm{r}^{2}=0.615(\mathrm{p}<0-0001), \mathrm{n}=$ 22; $-12^{\circ} \mathrm{C}: \mathrm{r}^{2}=0.352(\mathrm{p}<0.01), \mathrm{n}=18 ;-20^{\circ} \mathrm{C}: \mathrm{r}^{2}=0.00$ (n.s.), $\mathrm{n}=14$.

Fig. 3. Formaldehyde production in the muscle of whole hake during frozen storage. Regression lines were plotted; coefficients $\left(\mathrm{r}^{2}\right)$, significance and number of individuals analysed (n) were as follows: $-5^{\circ} \mathrm{C}: \mathrm{r}^{2}=0.508(\mathrm{p}<0.01), \mathrm{n}=22 ;-12^{\circ} \mathrm{C}: \mathrm{r}^{2}=0-352(\mathrm{p}<$ $0.01), \mathrm{n}=18 ;-20^{\circ} \mathrm{C}: \mathrm{r}^{2}=0.056$ (n.s.), $\mathrm{n}=15$.

Fig. 4. Dimethylamine (DMA-N) production in the muscle of whole hake during frozen storage. Regression lines were plotted in each case; coefficients $\left(r^{2}\right)$, significance and number of individuals analysed (n) were as follows: $-5^{\circ} \mathrm{C}: \mathrm{r}^{2}=0.876(\mathrm{p}<0.0001)$, $\mathrm{n}=$ $13 ;-12^{\circ} \mathrm{C}: \mathrm{r}^{2}=0.091$ (n.s.), $\mathrm{n}=16 ;-20^{\circ} \mathrm{C}: \mathrm{r}^{2}=0.042$ (n.s.), $\mathrm{n}=15$.

Fig. 5. Bound FA in the muscle of whole hake during frozen storage. Regression lines were plotted in each case; coefficients $\left(\mathrm{r}^{2}\right)$, significance and number of individuals analysed (n) were as follows: $-5^{\circ} \mathrm{C}: \mathrm{r}^{2}=0.780(\mathrm{p}<0.001), \mathrm{n}=13 ;-12^{\circ} \mathrm{C}: \mathrm{r}^{2}=0.023$ (n.s.), $\mathrm{n}=16 ;-20^{\circ} \mathrm{C}: \mathrm{r}^{2}=0.002$ (n.s.), $\mathrm{n}=15$.

Fig. 6. Decrease of $1 \% \mathrm{NaCl}$-soluble protein in the minced muscle containing added FA (unfrozen samples taken as $100 \%$ solubility).

Fig. 7. Decrease of $5 \% \mathrm{NaCl}$-soluble protein $\mathrm{m}$ the minced muscle containing added FA (unfrozen samples taken as $100 \%$ solubility).

Fig. 8. Formation of dimethylamine (DMA-N) in minced muscle containing added FA 